"Mircea cel Batran" Naval Academy Scientific Bulletin, Volume XIX - 2016 - Issue 1

Published by "Mircea cel Batran" Naval Academy Press, Constanta, Romania // The journal is indexed in:

PROQUEST / DOAJ / DRJI / JOURNAL INDEX / I2OR / SCIENCE LIBRARY INDEX / Google Scholar / Crossref /

Academic Keys / ROAD Open Access / OAJI / Academic Resources / Scientific Indexing Services / SCIPIO

\title{
INDICATORS APPLIED TO HIGHLIGHT THE VALORIZATION OF HUMAN CAPITAL IN SHIPPING
}

\author{
Filip NISTOR ${ }^{1}$ \\ Catalin POPA ${ }^{2}$ \\ Imre RECZEY ${ }^{3}$ \\ ${ }^{1}$ Senior Lecturer, PhD, Naval Academy, Constanta, Romania \\ ${ }^{2}$ Associate Professor, Naval Academy, Constanta, Romania \\ ${ }^{3}$ Head of Business Department, PhD, ADMC-Higher Colleges of Technology, United Arab Emirates
}

\begin{abstract}
In recent years, the shipping companies reconsidered their position regarding the importance of human capital because of the new trend in shipbuilding in conjunction with the enforcement of tighter regulations in shipping. Increasing profit of shipping companies was the result of valorization of human capital on board ships through acquirement of new skills and knowledge in accordance with technologies implemented on the new ships by training and development. Thus, identification of indicators that can be used to highlight the valorization of human capital in shipping is helpful. Measurement of indicators presented in this article can assist decision makers in identifying the best courses of action to improve human capital in shipping.
\end{abstract}

Keywords: human resources, indicators, valorization, shipping, human capital

\section{INTRODUCTION}

In the early twentieth century, economists such as Irving Fisher, Jacob Mincer and Léon Walras, included human capital within available capital and it has been used for correlation between the fundamental incomes in economics and level of education of the person. (Voicu, 2004).

The concept of human capital has been imposed in the economic literature since the 1960s by Theodore W. Schultz and Gary S. Becker, reaching his maximum level of interest in the seventh decade of the last century (Blaug, 1985). Becker follows the line of the Chicago School, initiated by Theodore Schultz, focusing in his work on the analysis of the relationship between changes in incomes resulting from economic activities and human capital, depending on the level of education of the people. Theodore W. Schultz was known by published studies that highlight the idea that man is the most valuable wealth of a country.

Human capital theory developed by Schultz turns the analysis of the equilibrium on the labor market as the main instrument of economic study, view education as an investment. According to this theory, people revenues are increased substantially in accordance with enhancing of levels of education. So, investments in education correspond to an individual investment at which we apply a cost-benefit calculation, knowing that simultaneous with increasing chances for employment, will obtain a increase of profitability. A confirmation of Schultz's theory can be outlined on the seafaring labor market in Romania where officers (person with higher education) have higher incomes than rating (category that has low skill levels). This may be why some of ratings, usually those aged up to 40 , attend courses to become officers.

Education and training are a profitable investment, its value depending on the cost of education and earnings anticipated on the labor market. This theory is applied in shipping.

So, we can find people among Romanian seafarers who hold university degrees in other technical fields, but they made a change in career and chose to become a seafarer due to higher future income

Statistics on the labor market in Romania reinforce the claim that the share of unemployed with lower education is higher compared to those who hold a bachelor's degree fact that support Spence's theory on human capital (Spence, 1973).

Also, the vast majority of people who prefer to work outside Romania hold jobs underpaid compared to native wages highlighting the difference of productivity and on investments in education. Seafarer wages vary from one nationality to another although there is a level of standardization taking into account professional training required worldwide.

The concept of human capital appeared in official documents of the European Community in 1988, with reference to Europe's hope, lies in the intellectual and technical potential of its population, investment in human capital is a priority for all European countries. 


\begin{abstract}
"Mircea cel Batran" Naval Academy Scientific Bulletin, Volume XIX - 2016 - Issue 1
Published by "Mircea cel Batran" Naval Academy Press, Constanta, Romania /I The journal is indexed in: PROQUEST / DOAJ / DRJI / JOURNAL INDEX / I2OR / SCIENCE LIBRARY INDEX / Google Scholar / Crossref /

Academic Keys / ROAD Open Access / OAJI / Academic Resources / Scientific Indexing Services / SCIPIO
\end{abstract}

In the endogenous growth models, human capital is assimilated to a stock of knowledge economically valued and incorporated to person, measured by wage (Gleizes, 2000). Carson defines human capital as including activities related tasks, such as knowledge and skills related to communication, entrepreneurship and other attributes like proper receptivity to lifelong learning (Carson et al., 2004).

Otherwise, the concept that is mentioned above is approached as a mix of knowledge of employees in relation to their work skills, leadership skills, ability to take risks and the capability of finding solutions to problems (Bozbura et al., 2007). In this regard, efficient management of human capital in shipping gives rise to great potential for value creation, and therefore can not be ignored intangible assets of shipping companies.

\section{INDICATORS CAN BE USED TO HIGHLIGHT VALORIZATION OF HUMAN CAPITAL IN SHIPPING}

The central role of human capital is to stimulate growth by improving productivity and promoting technological innovation through education and training programs (Son, 2010).

Professional training aims to create conformist attitudes and submitting to the demands of the workplace while the education system is dominated by capital. Thus, in the maritime transport the crew must fulfill certain requirements, starting from the level of knowledge up to quality of each individual personality, all those related to the tasks on board ships.

Identifying of some indicators for highlighting valorization of human capital in shipping can improve education and training programs developed by the countries that provides workforce in shipping.

Valorization of human capital along with fulfilling the conditions for increasing participation in the labor market in shipping and systematic access to functions on board ships, regardless of the nationality of the shipowner, are priorities for the sustainable development of seafarers from any country.

Valorization of human capital in shipping companies may be evidenced using indicators, such as:

- transport capacity of the ship reported to number of crew members;

- ratio between the ton-mile unit and shipping company profits;

- level and dynamics of seafarers wages. Valorization of human capital in shipping companies can be identified as the ratio between the ship's transport capacity (in dwt) and number of seafarers on board.
According to the SOLAS regulations, on board a ship involved in activities of maritime transport must be a number of seafarers according minimum safe manning certificate.

In establishing the minimum number of seafarers is taken into account: the type and destination of the ship, ship size, level of automation of ship, state of the ship (underway, on the dock, at anchor).

This minimum number of seafarers was imposed by regulators to stop shipping companies to establish this number below the minimum safe manning, in the pursuit of profit.

Further, based on mandatory crew members, it is interesting to calculate the ratio between the ship's tonnage and the number of crew that are operating the ship in safety conditions. The results obtained show the behavior of shipping companies on the labor market in situations when the ship is loaded at maximum capacity or are at the anchor.

This analysis can be carried out only for maritime ships because minimum crew number for inland waterway vessel is not established according to the tonnage of the vessel but takes into account the length of the vessel or convoy engaged in transport.

Also a factor to be noted is the fact that the owner, in establishing the minimum safety manning must take into account the reglementation imposed by the flag of the ship.

For the future, the companies need to improve its ability of valorization of human capital due to technological development in shipbuilding and innovations in the management of transport business organization.

Another way of valorization of human capital for the shipping company it can be from the analysis of ratio between the ton-mile unit and shipping company profits.

Ton-mile unit is determined according to the amount of freight and distance crossed from port of loading to the discharge port by the ships.

What is important to note is that the ratio between the ton-mile unit and profits is linked to demand and supply on the market.

From the analysis of ton-mile unit in 2012 was an increase of 58\% compared to 2000 (Crowe, 2013). This increase was due to an increased of transport capacity of the ship, while for average transport distance has been registered an increase of only $0.5 \%$.

The fact that ships will carry more can led to revenue growth which, combined with keeping the average distance of transport can be transposed into increased of ships profits. This increase would be adjusted only by other operating costs. 
"Mircea cel Batran" Naval Academy Scientific Bulletin, Volume XIX - 2016 - Issue 1

Published by "Mircea cel Batran" Naval Academy Press, Constanta, Romania // The journal is indexed in: PROQUEST / DOAJ / DRJI / JOURNAL INDEX / I2OR / SCIENCE LIBRARY INDEX / Google Scholar / Crossref /

Academic Keys / ROAD Open Access / OAJI / Academic Resources / Scientific Indexing Services / SCIPIO

Increasing shipping companies profit was the result of valorization of human capital onboard, who, through training learned new skills and knowledge that make it easier to conduct complex activities on the new ships with a cut of crew members.

The salary is another indicator of valorization of human capital in shipping by acting as a means of ensuring a balance between supply and demand in the labor market. For determining of salary should be considered aspirations of seafarers.

Apart from the general conditions of employment, providing an overview of the labor market in shipping is related to wages for seafarers.

Basic salary for seafarers has been proposed in the conventions and has been used as an argument in the actions which have discussion about minimum wages of seafarers. Seafarers from developed countries receive much higher wages than the minimum required by the International Labour Organisation, while seafarers from poor and developing countries have minimum wages, the owners arguing that higher wages is constraining to a bigger effort in terms of costs (Bergantino, 1998). The International Labour Organization adopted a recommendation which refers to the minimum monthly wage for the position of helmsman, agreed at the consultation between the International Chamber of Shipping and the International Transport Workers' Federation.

The minimum wage is determined by applying a settled formula that takes into account the existing price changes and fluctuations in foreign exchange or exchange terms of purchasing power parity.

Salary as a motivating role is all the more important as the wage level in the economy is reduced. Wage increase for seafarers as a factor to promote the profession leads to the accumulation of higher income compared to purchasing power (GDP / capita) with results that conduct to early retirement for seafarers and creation of new jobs in the maritime field.

Lately, wages were no longer a reason to choose sailor's profession for Europeans seafarers. Considering this, the specialised committee of the International Labour Organization together with shipowners was established in May 2011, an increase of minimum wage by $7.3 \%$ to $\$ 585$ and in 2016 it was set at $\$ 614$ valid until 2018 .

Despite the current economic climate, labor market wages in shipping have had an increasing trend for retention of specialised and experienced personnel in the field (Fig. $1 \mathrm{a}$ and no. 1b).

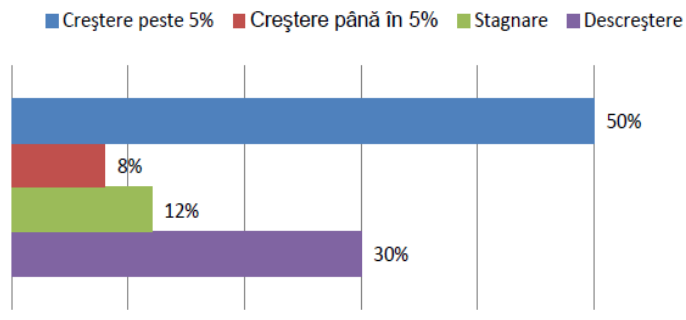

Figure 1a Modification of wages in 2012 compared to 2011, seafarers

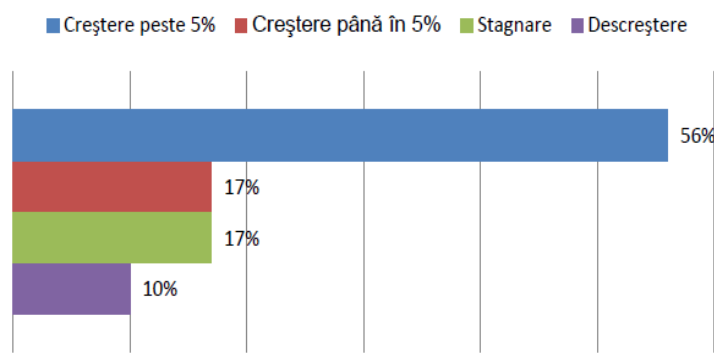

Figure 1b Modification of wages in 2012 compared to 2011, ashore personnel

Source: Faststream Recruitment Group, Maritime Employment Review, 2013

Generally, there isn't public information about the real wages of seafarers nationally. In some countries are mentioned statutory minimum wages or the collective agreements, but not specifically reflected in real wages. Furthermore, wages on collective agreements cover several types of ships and refer to bonuses that are hard to understand when they are applicable or not.

Based on analysis on the remuneration of persons that work in the maritime industry, relieved that, for seafarers an important aspect is the nationality (Table 1) and for ashore personnel is the geographical area of the job (Table 2) for a higher wage.

\begin{tabular}{|l|c|c|c|c|}
\hline & UE-15 & NMS-10 & Asia & $\begin{array}{c}\text { Nord } \\
\text { America }\end{array}$ \\
\hline Master & 138,320 & 109,627 & 111,422 & 135,000 \\
\hline $\begin{array}{l}\text { Chief } \\
\text { Engineer }\end{array}$ & 104,628 & 104,448 & 102,740 & 105,000 \\
\hline $\begin{array}{l}\text { Chief } \\
\text { Officer }\end{array}$ & 90,273 & 74,653 & 74,319 & 96,000 \\
\hline $\begin{array}{l}\text { Second } \\
\text { Engineer }\end{array}$ & 81,871 & 81,125 & 72,996 & 82,000 \\
\hline Ratings & 39,000 & 23,400 & 21,500 & 42,000 \\
\hline
\end{tabular}

Table 1 The annual salary for seafarers by geographical area in 2012, \$ (Faststream Recruitment Group, Maritime Employment Review, 2013)

Salary of seafarers differ significantly for the positions of master, chief officer and ratings 


\begin{abstract}
"Mircea cel Batran" Naval Academy Scientific Bulletin, Volume XIX - 2016 - Issue 1
Published by "Mircea cel Batran" Naval Academy Press, Constanta, Romania /I The journal is indexed in: PROQUEST / DOAJ / DRJI / JOURNAL INDEX / I2OR / SCIENCE LIBRARY INDEX / Google Scholar / Crossref /

Academic Keys / ROAD Open Access / OAJI / Academic Resources / Scientific Indexing Services / SCIPIO
\end{abstract}

entering in the area of well-paid, that is those with the nationality of the EU-15 and North America and those from Asia who have the lowest salaries of four areas studied. Asians are considered the cheapest labor market in shipping.

The high level of the salary of a shipmaster is due to experience and responsibilities on board. We must not forget that, to build a ship, the required period is between one to two years, while a shipmaster is formed in at least eight years in accordance with regulations.

In the European Union wages of officers are certainly higher than average wages of ashore personnel, although the difference is visible to officers at the operational level versus those at managerial level difference which is extremely important for seafarers from Europe East. Salary of seafarers from Romania (the NMS-10) is lower than in the EU-15 for most jobs but retain their superiority over remuneration of Asian seafarers.

\begin{tabular}{|l|c|c|c|c|}
\hline & Asia & Europa & USA & $\begin{array}{c}\text { Middle } \\
\text { East }\end{array}$ \\
\hline Charterer & 153113 & 121246 & 141444 & 111213 \\
\hline $\begin{array}{l}\text { Technical } \\
\text { Manager } \\
\text { Shipping } \\
\text { Company }\end{array}$ & 120613 & 129786 & 130867 & 110191 \\
\hline $\begin{array}{l}\text { Personnel } \\
\text { Manager - } \\
\text { Shipping } \\
\text { Company }\end{array}$ & 59963 & 59102 & 58265 & 57876 \\
\hline $\begin{array}{l}\text { Marine } \\
\text { Surveyor }\end{array}$ & 81291 & 69492 & 91045 & 79540 \\
\hline Shipbroker & 98325 & 78298 & 90981 & 65703 \\
\hline $\begin{array}{l}\text { Crane } \\
\text { operator }\end{array}$ & 51230 & 54660 & 60150 & 49860 \\
\hline
\end{tabular}

Table 2 The annual salary for ashore personnel by geographical area in 2012, \$ (Faststream Recruitment Group, Maritime Employment Review, 2013)

Instead, for ashore jobs in maritime industry, Asia is no longer on the lowest position, this place has been occupied by the Middle East, because ports in Asia are used as transit ports for major routes and at the same time constitutes the departure port of goods to area like Europe and America.

Salary, for Romanian seafarers, represents the main motivating factor in maintaining their profession rather than a job ashore.

The ratio between salaries of staff employed at a port operator and seafarers, starts at 1/3 for staff with secondary education and reach at $1 / 9$ for those with higher education in according to hierarchy. During this situation must be taken into account that wage employees of the port operator compares, primarily, to wages of jobs in the same geographic region, while wages seafarers of any region compares to global wages of seafarers.
Considering the high level of globalization of the shipping, an important indicator of valorization of human capital is the amount of remittances seafarers.

Table 3 shows the remittances of seafarers, values estimated during 2000-2012, depending on the number of crew members, officers and ratings, the average period spent on the ship and the net average wage.

\begin{tabular}{|l|c|c|c|c|}
\hline Year & $\mathbf{2 0 0 0}$ & $\mathbf{2 0 0 5}$ & $\mathbf{2 0 1 0}$ & $\mathbf{2 0 1 2}$ \\
\hline Remittance & 195 & 285 & 370 & 385 \\
\hline
\end{tabular}

Table 3 The values of remittances seafarers, 2000-2012 (selected years), mil. \$

As can be seen, remittances seafarers doubled in 2012 compared to 2000. The fact that seafarers represents work force highly specialized conduct to higher values of remittances than in other fields.

Remittances often contributes to an increased spending for education, increasing the stock of skills, a real benefit for the training and development of human capital in Romania. The prospect of well-paid jobs could serve as an incentive for investment in education and health, important pillars in promoting long-term economic growth for a country.

Valorization of positive impact of human capital migration in shipping by maximizing the potential growth of remittances, results in stimulating economic activity in the short term. In this regard, the State should include in its priorities, policies and measures to facilitate investment of remittances in the national economy.

Remittances sent by seafarers can have a multiplier effect on the households, being used for investments which reduce constraints of crediting and providing new opportunities for entrepreneurship, stimulating certain sectors of the economy.

Taking into account that the seafarers is paid in foreign currency, remittances may have as a result a significant contribution to improving the balance of payments.

Concerns about the level of remittances in an economy are related to that remittances lead to an increase purchasing power without increasing labor productivity which may conduct to inflation.

But at the same time, remittances influence indirectly the demand for labor at local level, by reducing the number of hours worked by households that receive remittances.

Remittances are important mechanisms for the redistribution of dividends economic growth. There are wider benefits for society with a highly skilled workforce in shipping, which can work 
"Mircea cel Batran" Naval Academy Scientific Bulletin, Volume XIX - 2016 - Issue 1

Published by "Mircea cel Batran" Naval Academy Press, Constanta, Romania // The journal is indexed in:

PROQUEST / DOAJ / DRJI / JOURNAL INDEX / I2OR / SCIENCE LIBRARY INDEX / Google Scholar / Crossref /

Academic Keys / ROAD Open Access / OAJI / Academic Resources / Scientific Indexing Services / SCIPIO

ashore in maritime industry or in other industry after a long period spent on board ships. Thus, the community as a whole will benefit from valorization of human capital in shipping.

\section{CONCLUSIONS}

Establishing ways of valorization human capital in shipping with a labor market that are functioning with his proper particularities, highlights the ability of seafarers to acquire new skills and thus to make its contribution to technological changes.

In conclusion, we can say that monitoring the actions of valorization human capital in shipping may lead to an allocation of human resource and an adaptive management of funds both for the state and the companies concerned, which will contribute to the initiation and exploitation of synergies within various programs in training and development of human capital.

The actions of developing other ways to valorization of human capital will also follow, best practice and experience in maritime transport bring out by stakeholders.

\section{BIBLIOGRAPHY}

[1] Bergantino, A., Marlow, P., Factors Influencing the Choice of Flag: Empirical Evidence, Maritime Policy and Management, 1998

[2] Bozbura, F. T., Beskese, A., \& Kahraman, C., Prioritization of Human Capital Measurement Indicators Using Fuzzy AHP, Expert Systems With Applications, no. 32, p. 1100-1112, 2007

[3] Carson, E., Ranzijn, R., Winefield, A., Marsden, H., Intellectual Capital. Mapping Employee and Work Group Attributes, Journal of Intellectual Capital, no. 5, p. 443-463, 2004

[4] Chitac, V., Toma, A., Atodiresei, D., Integrated Management System for Intervention in Maritime Accidents and Distress Situations on the Black Sea, "Mircea cel Batran" Naval Academy Scientific Bulletin, Volume XVII, Issue 2, ISSN 1454-864X, Constanta, 2014

[5] Crowe T., Seaborne Trade: The Long and The Short of It, Shipping Intelligence Network, 2013

[6] Gary Becker, Capitalul uman. O analiză teoretică şi empirică cu referire specială la educaţie, Editura ALL, Bucureşti, 1997

[7] Faststream Recruitment Group, Maritime Employment Review, 2013

[8] Jérôme Gleizes, Le capital humain 2. Nouvelle économie politique, Paris, 2000

[9] International Organization for Migration, Migration Development, 2010

[10] Oxford Economics, The Economic Value of the EU Shipping Industry, A report for the European Community Shipowners' Associations, 2014

[11] Son, H., Human Capital Development, Asian Development Bank, Manila, 2010

[12] Voicu, B., Capitalul uman: componente, niveluri, structuri. România în context European, Revista Calitatea Vieţii nr. 1-2, Bucureşti, 2004 